\title{
Let’s Talk About Same Sex: How Social Workers Can Make Judges Listen
}

\author{
Stephanie K. Boys
}

\begin{abstract}
Researchers have created a diverse toolbox of literature reporting that same sex cohabitating relationships are strikingly similar to heterosexual marriages in amicus curiae briefs submitted to the courts. However, judges are trained to fit information into legal frameworks and to ignore data that does not fit the rhetoric of a case. The following article aims to fit existing data on same sex relationships into the framework judges will use to decide whether same sex marriage can be prohibited. The primary precedent used to support same sex marriage is based on the analogy of a case prohibiting marriage discrimination based on race. The legal framework created by this case requires social work policy practitioners to frame research in terms of the evolution that has occurred in scientific understanding of same sex attraction and public opinion. A simple shift in the discourse used to frame the data can significantly impact whether judges listen.
\end{abstract}

Keywords: Policy practice, same sex marriage, discrimination, discourse, social policy

\section{INTRODUCTION}

The purpose of this article is to situate the social science literature on same sex marriage into a legal context useful in a courtroom. The National Association of Social Workers (NASW) has been an active participant in advocating for same sex marriage in the legal arena through amicus curiae briefs and testimony in previous cases. The evidence that homosexual couples form relationships equivalent to married heterosexual couples has been clearly stated; however, judges are trained to ignore evidence that is not relevant to the legal framework from which they must decide a case.

The case of Loving $v$. Virginia (1967) provides one of the likely legal precedents that will be used to frame and decide whether same sex marriages can be denied for public policy reasons. The case established that states cannot ban interracial marriage, and the similarity to state bans on same sex marriage has created a legal argument advocates call the Loving analogy. The analogy is explained in the first section of this article. The next section explores ways to incorporate social science data into the framework of the Loving analogy. In explaining these data, advocates should employ a discourse focused on the evolution of both scientific understanding of homosexuality and the evolution of public opinion. The admitted ignorance of the Court regarding issues of sex and intimacy underscores the importance of advocacy by policy practitioners. By placing the current social science literature in the context of the legal precedent, advocates can make this literature relevant for judges who have been trained in law rather than social science.

\section{THE IMPORTANCE OF COURTROOMS TO THE FUTURE OF MARRIAGE IN THE UNITED STATES}

On June 17, 2008, California courthouses were flooded with same sex couples filing for legal marriage licenses for the first time. It was a day shrouded with controversy.

Stephanie K. Boys, Ph.D., JD, MSW, is an Assistant Professor in the Indiana University School of Social Work on the Indianapolis campus.

Copyright (c) 2010 Advances in Social Work Vol. 11 No. 2 (Fall 2010), 117-128 
Advocates of same sex marriage rights celebrated in the streets, while opponents protested. The celebrations, as well as marriage ceremonies of same sex couples, ceased only a few months later when a public referendum passed and voided legislation that had permitted the marriages. However, turmoil erupted once again on August 4, 2010 when the case of Perry v. Schwarzenegger was decided in the United States District Court for the Northern District of California. The decision invalidated public referendum proposition 8 , but it is unlikely we have heard the last word on this issue as opponents are at work on arguments to appeal.

Currently, the issue of whether to solemnize same sex marriages in the United States is addressed on a state by state basis. The legality of same sex marriage is in flux across the United States. As of the writing of this article, six states grant same sex couples marriage licenses; however, unlike most other couples who marry in the United States, these marriages may not be recognized if the couples travel or relocate to another state.

In order to adapt to the frequent migration of United States' citizens from state to state, the states honor most marriages performed in other states and grant those couples the same rights and privileges of couples married within the state. However, the Supreme Court has validated some exceptions to marriage recognition on public policy grounds, such as if another state were to permit polygamous or incestuous marriages (Strasser, 1998). To ensure states could add same sex unions to the small list of public policy exceptions, Congress passed the Defense of Marriage Act (DOMA) in 1996. This federal legislation permitted states to outlaw same sex marriage and treat those marriages as void within the state. However, the confusion and turmoil caused by varying laws will require the Supreme Court to address the validity of DOMA and state laws invalidating same sex marriages performed in other states in the near future.

Although advocacy for same sex union legislation is important, courtrooms are the focal concern because most legislation on same sex marriage is challenged on the state level, and it is likely either a case challenging DOMA or a state law will be accepted for review by the Supreme Court. The laws certainly raise a Constitutional issue regarding $14^{\text {th }}$ Amendment equal rights; the Court, however, routinely waits to accept review of controversial issues until public sentiment on the issue is more settled (Perry, 1991). Due to the inclusive nature of Supreme Court decisions and the Court's reluctance to overturn decisions once made, it is imperative that social work practitioners be prepared when the case comes before the Court.

\section{THE LOVING ANALOGY}

Another instance in US history when marriages could be voided for public policy reasons by states objecting to the union was the invalidation of interracial marriages. In 1967, sixteen states voided interracial marriages performed in other states. This practice

was determined to be unconstitutional by the United States Supreme Court under the $14^{\text {th }}$ Amendment of the Constitution, as a discriminatory practice based on race (Loving $v$. Virginia, 1967). 


\section{History of the Case}

The historic lawsuit was brought by Richard Loving and Mildred Jeter, who wed in 1958 in Washington, DC (Pratt, 1998). Mildred and Richard returned to Virginia and moved into her parents' home. About a month later, the two were awakened when the county sheriff entered the unlocked home and found the couple asleep in their bedroom. The two were charged with unlawful cohabitation after being told their District of Columbia marriage license was "no good here” (Pratt, 1998, p. 236). The Virginia 1924 Racial Integrity Act automatically held void all marriages between a white person and a "colored" person. It also prohibited recognition of legal marriages permitted in other states (Loving v. Virginia, 1967).

When the law was challenged in front of the US Supreme Court, the Lovings' attorney argued that Virginia's statute invalidating interracial marriages violated the Equal Protection and Due Process Clauses of the $14^{\text {th }}$ Amendment of the US Constitution. Virginia supported the law by arguing that it was non-discriminatory because it treated white persons and black persons equally since neither was permitted to enter into an interracial union. The Supreme Court did not accept Virginia's argument and held that the facial, or explicit, classification based on race could not stand under the Equal Protection Clause (Loving v. Virginia, 1967).

The reasoning needed to overturn the Virginia law was completed at this point, and the opinion could have been finished and signed by the members of the Court. However, the opinion did not stop there. Even though the case could have rested completely upon the Equal Protection Clause, the Court chose to also address the issue of Substantive Due Process raised by the Lovings' attorney. Over time, precedent has established that certain fundamental rights, as defined by the Supreme Court, cannot be infringed by the states under the $14^{\text {th }}$ Amendment by what has become known as Substantive Due Process. In Loving, the Court recognized marriage as one of those fundamental rights. The opinion stated marriage is a basic right of man, "fundamental to our very existence and survival" (p. 12).

\section{How the Precedent is Used by Advocates of Same Sex Marriage}

The invalidation of anti-interracial marriage laws has been the primary precedent for legal advocates arguing for same sex marriage rights across the United States. The argument follows that, as stated by the majority opinion in the Loving case, the "Fourteenth Amendment requires that the freedom of choice to marry not be restricted" (Loving v. Virginia, p. 12). This establishment of marriage as a fundamental right set the stage for what has been termed the Loving analogy (Morrison, 2007). The analogy reasons that Loving is precedent for permitting same sex couples to marry. Advocates argue that freedom to marry means freedom to marry, and that it applies equally to all subordinated groups in society. Although the Court specified that choice of marriage partner could not be restricted by race, the language used by the court was gender neutral. Additionally, although gender classifications have traditionally received a lower level of scrutiny than racial classifications under Equal Protection doctrine, the Court's addition

of marriage as one of the fundamental rights allows same sex marriage to be supported 
under the Due Process Clause instead of Equal Protection, making the difference between classifications based on race and gender moot.

\section{How the Precedent is Used by Opponents of Same Sex Marriage}

Although the Court has granted freedom of whom to marry, it must be acknowledged that this quote is often used out of context. The full quote reads, the "Fourteenth Amendment requires that the freedom of choice to marry not be restricted by invidious racial discriminations" (Loving $v$. Virginia, p. 12). The choice of whom to marry as a fundamental right has been touted by the legal community supporting same sex marriage with little question to the fit of the precedent. It seems logical that if choice of who to marry is a fundamental right, the gender of that person should be a moot point. However, opponents of same sex marriage have developed several strong arguments to puncture the arguably solid fit of the precedent established in Loving for the invalidation of laws prohibiting choice of a same sex marriage partner.

The primary retort made by both legal scholars and much of the public in opposition to the legal recognition of same sex marriages is that if the Loving precedent is extended beyond race, marriage will be set upon a slippery slope that could end in the recognition of unfathomable unions, such as man and livestock or polygamist unions with one groom and 30 wives (Andreasen, 2003). Though some public figures have dramatized this argument to a laughable extent, the legal argument does remain sound when considering that marriage has never been an unrestricted freedom. Legislatures have been permitted to regulate some elements of who may marry for public policy concerns, such as the age of consent to marry, the prohibition against incest marriages, as well as the elements that permit the dissolution of a marriage (Andreasen, 2003).

Another strong retort to the Loving analogy is that the Supreme Court has already decided that Loving does not extend to same sex couples. Just five years after Loving was decided, two men in Minnesota filed suit when their marriage license application was rejected (Baker v. Nelson, 1971). The case to invalidate Minnesota's ban on same sex marriage relied primarily on the Loving analogy. The Minnesota Supreme Court rejected the argument stating that it was not directly supported by US Supreme Court precedent. It is likely Minnesota was not ready to extend the Loving decision regarding such a controversial subject without explicit approval by the US Supreme Court. The US Supreme Court was not willing to give this approval. The couple appealed the case to the Supreme Court, who dismissed the claim for lack of a substantial federal question (Baker v. Nelson, 1972). Legal opponents of same sex marriage, Wardle and Oliphant, use this point to argue that utilizing Loving as precedent for invalidating same sex marriage bans is a "first-semester law student kind of error," and illustrates a lack of thorough research, since they assert that Baker v. Nelson was the final answer in whether Lovings' precedent extends to same sex couples (2007, p. 137). As taboo as it is to appear to be using "bad law," the idea that Baker v. Nelson settled the law is far from a thorough examination of the issue. Although at the time Baker was dismissed this was interpreted as an indication of a correct interpretation by the lower court, the Supreme Court was also declining cases they were not yet ready to decide. Additionally, although the Court attempts to maintain consistent precedents, it has always been permitted to overrule earlier precedent if it can 
be deemed that society has evolved to a point where the earlier precedent is no longer sustainable under public policy considerations.

\section{FRAMING ADVOCACY DISCOURSE FOR THE COURTROOM}

A common way social science research is presented to the courts is through submission of an amicus curiae brief. These briefs are used to provide information to the court regarding the impact of a potential court decision upon society rather than just the individuals involved in the current case. Social workers have teamed with psychologists and other social scientists to write amicus curiae briefs submitted in previous court cases in support of same sex marriage (American Psychological Association et al., 2007). A debate has been waged over whether the discourse of the briefs should be focused on mental health or social justice (Kitzinger \& Wilkinson, 2004). This author proposes that in the courtroom, issues of both social justice and mental health can be relevant so long as they are discussed in a discourse that is used by judges.

The purpose of law school is often said to be to teach students to think like lawyers (Wetlaufer, 1990). This means learning the rhetoric by which opinions must match a framework based on legal precedent, or decisions that have been written by previous judges. The principles of previous cases must be determined, and then similar cases must be decided based on those principles. Material that is not relevant to the principles is not relevant to the case. Therefore, in order to garner the attention of judges, discourse regarding social science data must match the rhetoric of the principles. A simple change in the discourse used to discuss the data can greatly impact the weight it is given in a judge's decision (Wetlaufer, 1990).

In connection to same sex marriage jurisprudence, one of the leading precedents is Loving v. Virginia. The question the Court will be called upon to answer is whether the precedent that marriage choice cannot be infringed based on race should be interpreted as expanding to include marriage infringement based on gender. Utilizing the precedent of Baker v. Nelson (1972), the opposition will argue the Supreme Court of 1967 did not intend the Loving case to be interpreted so broadly. Legal advocates for same sex marriage will counter that knowledge and public opinion about gay marriage has evolved to broadly prohibit any infringement upon the choice of whom to marry. If the Court were not permitted to expand previous principles, schools could still be segregated and executions permitted for robbery. The US Constitution, and the government it created, has been able to govern effectively because of the Supreme Court's ability to interpret using evolving standards. Therefore, social work advocates who frame the social science data in discourse focused on evolution of knowledge and public opinion will fit the decision framework of judges and garner more attention to their words.

\section{THE EVOLUTION OF SOCIAL SCIENCE DATA AND HOW IT CAN STRENGTHEN THE LOVING ANALOGY}

Wardle and Oliphant have shown in a recent study of state cases and law journals that Loving is often used in law review articles supporting same sex marriage, but the analogy has rarely been successful when actually tested in court (2007). The remainder of this 
article will explore discourse that can strengthen the precedent of the Loving analogy in response to the case the opposition has been building. The better the fit between the discourse in the amicus briefs, testimony and the legal precedent, the more likely the information will sway the justices. The literature must be discussed in a discourse focusing upon the evolution of society. Evolution has occurred in stages. First, the scientific community shifted from understanding homosexuality as a disease to a healthy lifestyle. Next, studies were conducted that changed understanding of homosexual relationships as "different" from to very similar to heterosexual relationship dynamics. Finally, evidence is showing a progressive societal evolution toward acceptance of same sex unions.

\section{Evolution of the Scientific Understanding of Same Sex Attraction}

In US history, it is well known that the scientific community used data to support the racial inferiority of African Americans and justify discrimination propagated against the race. However, it is often ignored that scientific evolution of the understanding of a group may be even more profound for homosexual men and lesbian women. Although it has been acknowledged that the Supreme Court dismissed a claimed violation of Due Process and Equal Protection for same sex couples wishing to marry, this case was decided in 1972 (Baker v. Nelson). Since that time the scientific community has greatly evolved in its understanding of the nature of sexual orientation. In order to fit courtroom discourse, it is imperative social workers advocating for same sex marriage frame the evidence in terms of a new understanding of homosexuality.

The first shift in scientific understanding was made in the Diagnostic and Statistical Manual of Mental Disorders (DSM) categorization of homosexuality. The first two editions of the DSM, published by the American Psychiatric Association (APA) and used as the primary diagnostic authority by the medical, psychological and social work communities in the United States, defined homosexuality as a mental disorder until 1973 (Goishi, 1997). In 1973, same sex orientation was not removed from the DSM, but rather was downgraded to sexual orientation disturbance. Prior to the change in terminology, all persons attracted to the same sex were considered to have a disease which could be treated with psychotherapy. The change in the third edition was made because the Board of Trustees of the APA voted, "a significant portion of homosexuals are apparently satisfied with their sexual orientation, show no significant signs of manifest psychopathology...and are able to function socially and occupationally with no impairment" (APA, 1980, p. 380). Therefore, only those "disturbed by, in conflict with, or wish[ing] to change their sexual orientation" (APA, 1980, p. 380) were subsequently diagnosed with sexual orientation disturbance, which was later changed to ego-dystonic homosexuality and then eliminated in the fourth edition (APA, 1987).

Today, in the DSM-IV-TR, there is a category of sexual and gender identity disorders, but it has been explained to only pertain to those who experience conflict from their sexual orientation rather than per se to all those experiencing same sex attraction (APA, 2000). Some scholars still assert that the DSM should be interpreted as encouraging the treatment of gender identity disorders in childhood, and that successful treatment can prevent homosexuality later in life (Rekers, 1995); however, the majority of the mental 
health community diagnoses with the purpose of resolving the emotional conflict without regard to the outcome of the patient's adulthood sexual orientation (Goishi, 1997). This discourse of evolution of the diagnosis of homosexuality must be stressed in amicus curiae briefs and testimony in order to illustrate how vastly the scientific understanding of sexual orientation has changed since the Court case decided in 1972.

\section{Evolution of the Understanding of Same Sex Relationships}

Since acknowledgement by mental health professionals that same sex attraction is not a disease, many studies have been conducted to assess the similarities and differences between heterosexual and homosexual relationships. After a thorough review of these studies spanning several decades, an amicus curiae brief submitted by the National Association of Social Workers, the American Psychological Association, and several other professional organizations reported same sex couples form committed relationships in the same ways as heterosexual couples (American Psychological Association et al., 2007). Findings further indicate persons with same sex attraction desire committed relationships. In a 2000 poll, 74\% of a randomly sampled pool of lesbian women, gay men and bisexual persons stated that they would like to be married to a partner of the same sex if it were permitted (Henry J. Kaiser Foundation, 2001).

The amicus curiae brief is an excellent, thorough and timely review of what science has learned about the nature of same sex relationships (American Psychological Association et al., 2007). Whether same sex relationships have changed cannot be known since it was not empirically studied at length prior to the 1970s paradigm shift from homosexuality as a dysfunction; however, the understanding of the relationships has greatly changed. It has gone from little knowledge to a host of studies demonstrating that issues from desire for commitment to topics of conflict are similar among heterosexual and homosexual couples (Kurdek, 2004). It is this evolution since the Baker v. Nelson decision in 1972 that must be stressed in order to persuade the Court to dismiss arguments that the case is a ruling precedent. Discourse must specifically state that what we know about same sex relationships and their similarity to heterosexual married relationships has evolved greatly since 1972 .

The tactic of persuading judges to understand homosexual relationships as analogous to heterosexual relationships very recently gained empirical support through the success of Theodore Olson's arguments in front of Judge Walker on the issue of overturning Proposition 8. Olson is a self-pronounced conservative and was appointed solicitor general by former President George W. Bush. However, he recently represented several same sex couples in a lawsuit that overturned California's Proposition 8 ban on same sex marriage (Perry v. Schwarzenegger, 2010). Olson's strategy to change public and judicial opinion regarding same sex marriage is to show that legalization will actually encourage conservative family values as more couples are formally united (Olson, 2010). He further argues that encouraging marriage will strengthen communities both socially and economically through the increase in legal unions of two persons for a lifelong commitment toward family stability (Olson, 2010). 


\section{Evolution of Public Opinion}

Although social science knowledge has evolved to understand cohabitating same sex couples to be similar to heterosexual married couples, the obvious counter by opponents is, regardless of knowledge, the general public is still opposed to legalizing same sex marriage. While reviewing the published literature on same sex marriage, many discussions of the previous studies and data are written in a way that stresses how much opinions have changed to favor same sex marriage (Andersen \& Fetner, 2008). Although there has been an increased acceptance, the percent of Americans who favor legalizing gay marriage is still only about one-third. In a 2004 survey, the number of Americans reported to support gay marriage was 33\%, while $49 \%$ support legalizing civil unions (Avery et al., 2007).

However, the discourse of evolution is a perfect linguistic fit with evidence on public opinion regarding same sex relationships. Public opinion has been evolving in the direction of support. The level of increase has surprised even those who study changes in generational cohort attitudes and other sex-related issues.

The youngest generational cohort of adult Americans has been termed the "millennials". This generation has shown almost a reversion to traditional family values of monogamy, however, they do not seem to care if the monogamy is between homosexual or heterosexual couples (Howe \& Strauss, 2000). Acceptance of same sex relationships is inversely correlated with age, that is, increasing with younger generations; therefore, if the current trend progresses, Americans will become more accepting over the next few decades (Howe \& Nadler, 2009).

Recent studies indicate the evolution of acceptance of homosexuality may increase even faster than through evolution of younger cohorts coming into power. Most research shows that social attitudes of generational cohorts tend to remain static from the time the generation reaches adulthood (Howe \& Nadler, 2009); however, tolerance of homosexuality has been found to be an exception (Anderson \& Fetner, 2008). Although the time period when change occurred is debated, by the year 2000, American attitudes had shifted substantially among older cohorts in the direction of support for gay unions (Smith, 1992; Yang, 1997; Loftus, 2001). Treas (2002) found that public opinion on same sex relationships has changed far more dramatically than on any other sex-related issue, illustrating the unique increase in public support.

Anderson and Fetner (2008) found the phenomenon of increased social support was even stronger in Canada than the United States. The authors theorized the legalization of same sex marriage in Canadian public policy could have spiked public acceptance. If same sex marriage was legalized across the United States, would the same spike occur in US public opinion?

\section{RECOMMENDATIONS \& FUTURE DIRECTIONS}

The purpose of this article was to place social science research on same sex relationships into a discourse social work policy practitioners can use in future amicus curiae briefs and testimony before judges. Increasing the toolbox of research knowledge 
available for social workers to place in the framework will be important as US public policy on same sex marriage continues to change quickly and is often seen in courtrooms across the country. Now that some states have granted marriage certificates to same sex couples, it will be imperative to assess the impact on public opinion. Will the state government's acceptance of same sex marriage increase acceptance similar to that seen in Canada after the legalization of same sex marriage? If so, this evolution of public opinion as more states legalize same sex marriage could be set in a discourse of evolving societal standards that would certainly pique the ears of the US Supreme Court members who have been trained to incorporate evolving societal standards into their decisions.

Additionally, social work education must be expanded to include discourse on the evolution of the understanding of same sex attraction and public opinion. Unless students are educated regarding the historical struggle for equality same sex couples have already endured, future social workers will not be able to provide the type of advocacy suggested by this author.

Finally, the future discourse on same sex marriage advocacy must be extended to be inclusive of the gay, lesbian, bisexual and transgendered (GLBT) population. Strategists have thus far kept discussion focused on relationships between gay men and lesbian women in order to garner the widest range of support; however, for true equality to be achieved, the discourse must work toward evolving to include other subsets of the GLBT community.

\section{CONCLUSION: THE DUTY TO ADVOCATE}

Social workers advocating for same sex marriage must educate the Court regarding the evolution of society in order to strengthen their case that the Loving analogy of freedom to marry should extend to same sex couples. Judges themselves have illustrated that they are not socially educated regarding sex and intimacy. Judge Posner has written

"Judges know next to nothing about the subject [of sex] beyond their own personal experience, which is limited, perhaps more so than average, because people with irregular sex lives are pretty much (not entirely, of course) screened out of the judiciary - especially the federal judiciary, with its elaborate preappointment investigations by the FBI and other bodies. This screening, along with the gap, for which the screening is in part responsible, in judges systematic knowledge of sex is a residue of the nation's puritan - more broadly of its Christian - heritage. Another residue is the large body of laws regulating sex which judges are called on to interpret and apply, and sometimes asked to invalidate" (Posner, 1992, p. 1).

Justice Powell has also stated he has never known a homosexual (Hermann, 2005).

Some judicial decision makers who will ultimately be deciding the rights of same sex couples admittedly have no knowledge regarding the lives of persons with same sex attraction. Therefore, advocates for same sex marriage must be prepared with as much ammunition as possible to persuade and educate legal decision makers. Research in the

area of same sex relationships is plentiful; however, it must be presented to judges in a 
discourse that will be relevant. Scientific knowledge and public opinion have evolved, and it is time to tell the Court.

\section{References}

American Psychiatric Association. (1980). Diagnostic and statistical manual of mental disorders ( $3^{\text {rd }}$ ed.). Washington, DC: Author.

American Psychiatric Association. (1987). Diagnostic and statistical manual of mental disorders (Revised $3^{\text {rd }}$ ed.). Washington, DC: Author.

American Psychiatric Association. (2000). Diagnostic and statistical manual of mental disorders (Revised $4^{\text {th }}$ ed.). Washington, DC: Author.

American Psychological Association, California Psychological Association, American Psychiatric Association \& National Association of Social Workers. (2007, September 26). In re Marriage Cases. Case No. S147999. Retrieved from http://www.apa.org/about/offices/ogc/amicus/marriage-cases.pdf

Andersen, R., \& Fetner, T. (2008). Cohort differences in tolerance of homosexuality: Attitudinal change in Canada and the United States, 1981-2000. Public Opinion Quarterly, 72(2), 311-330.

Andreasen, K. (2003). Part two: Marriage and divorce: When, what, and where: Did Loving v. Virginia need its slippery slope? Journal of Contemporary Legal Issues, 14, 89-96.

Avery, A., Chase, J., Johansson, L., Litvak, S., Montero, D., \& Wydra, M. (2007). America's changing attitudes toward homosexuality, civil unions, and same-gender marriage: 1977-2004. Social Work, 52(1), 71-79.

Baker v. Nelson, 291 Minn. 310 (1971).

Baker v. Nelson, 409 U.S. 810 (1972).

Defense of Marriage Act (1996). 28 U.S.C. §1738C.

Goishi, M. A. (1997). Legal and social responses to the problems of queer youth: Unlocking the closet door: Protecting children from involuntary civil commitment because of their sexual orientation. Hastings Law Journal, 48, 1137- 1182.

Henry J. Kaiser Family Foundation. (2001). Inside-out: A report on the experiences of lesbians, gays and bisexuals in America and the public's views on issues and policies related to sexual orientation. Retrieved from http://www.kff.org/kaiserpolls/upload/National-Surveys-on-Experiencesof-LesbiansGays-and-Bisexuals-and-the-Public-s-Views-Related-to-Sexual-Orientation.pdf

Hermann, D. H. J. (2005). Pulling the fig leaf off the right of privacy: Sex and the Constitution. DePaul Law Review, 54, 909-969. 
Howe, N., \& Nadler, R. (2009, February). Yes we can: The emergence of millennials as a political generation. Retrieved from http://www.newamerica.net/files/Yes\%20We\%20Can.pdf

Howe, N., \& Strauss, W. (2000). Millennials rising: The next great generation. New York: Vintage.

Kitzinger, C., \& Wilkinson, S. (2004). Social advocacy for equal marriage: The politics of "rights" and the psychology of "mental health." Analyses of Social Issues \& Public Policy, 4(1), 173-194.

Kurdek, L. A. (2004). Are gay and lesbian cohabiting couples really different from heterosexual married couples? Journal of Marriage and Family, 66(4), 880-900.

Loftus, J. (2001). America's liberalization in attitudes toward homosexuality, 1973-1998. American Sociological Review, 66(5), 762-782.

Loving v. Virginia, 388 U.S.1 (1967).

Morrison, A. M. (2007). Same-sex loving: Subverting white supremacy through same-sex marriage. Michigan Journal of Race \& Law, 13, 177-225.

Olson, T. B. (2010, January 18). The conservative case for gay marriage: Why same-sex marriage is an American value. Newsweek, 155(3), 48-54.

Perry, H. W. (1991). Deciding to decide: Agenda setting in the United States Supreme Court. Cambridge, MA: Harvard University Press.

Perry v. Schwarzenegger, 591 F.3d 1147 (2010).

Posner, R. A. (1992). Sex and reason. Cambridge, MA: Harvard University Press.

Pratt, R. (1998). Crossing the color line: A historical assessment and personal narrative of Loving v. Virginia. Howard Law Journal, 41, 229-244.

Rekers, G. A. (1995). Handbook of child and adolescent sexual problems. New York: Lexington Books.

Smith, T. W. (1992). Attitudes toward sexual permissiveness: Trends, correlates, and behavioral connections. In A.S. Rossi (Ed.), Sexuality across the life course (pp. 6397). Chicago: University of Chicago Press.

Strasser, M. (1998). Baker and some recipes for disaster: On DOMA, covenant marriages, and full faith and credit jurisprudence. Brooklyn Law Review, 64, 307351.

Treas, J. (2002). How cohorts, education, and ideology shaped a new sexual revolution on American attitudes toward nonmarital sex, 1972-1998. Sociological Perspectives, 45(3), 267-283.

Wardle, L. D., \& Oliphant, L. C. (2007). In praise of Loving: Reflections on the "Loving analogy” for same-sex marriage. Howard Law Journal, 51, 117-186. 
Wetlaufer, G. B. (1990). Rhetoric and its denial in legal discourse. Virginia Law Review, 76(8), 1545-1597.

Yang, A. S. (1997). The polls—-trends: Attitudes toward homosexuality. Public Opinion Quarterly, 61, 477-507.

\section{Author's note:}

Address correspondence to: Stephanie K. Boys, Indiana University School of Social Work, 902 West New York Street, Education/Social Work Building, Room 4157, Indianapolis, IN 46202. Email: sboys@indiana.edu 